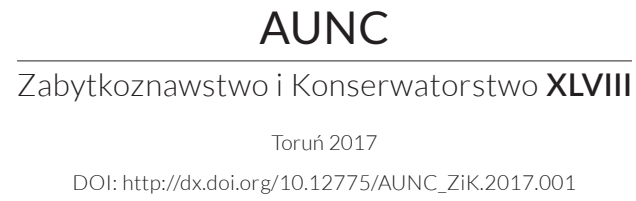

\title{
Historia budowlana późnoromańskiego kościoła w Tulcach koło Poznania w świetle badań architektonicznych
}

\author{
KAROLINA ZIMNA-KAWECKA \\ Zakład Konserwatorstwa, Wydział Sztuk Pięknych, UMK w Toruniu \\ e-mail:kzimka@umk.pl \\ MACIEJ PRARAT \\ Zakład Konserwatorstwa, Wydział Sztuk Pięknych, UMK w Toruniu \\ e-mail:mprarat@umk.pl
}

Keywords: Romanesque architecture, sacral architecture, conservation, architectural research, building techniques

Słowa kluczowe: architektura romańska, architektura sakralna, konserwatorstwo, badania architektoniczne, techniki budowlane

\begin{abstract}
History of construction of the late Romanesque church in Tulce near Poznań in the light of architectural investigation

The aim of this paper is to present a structural history of the late Romanesque church in Tulce (district Poznan). Noninvasive architectural research of the building was conducted in 2014. Its results were then confronted with the literature on the subject.

On this basis it was possible to identify structural changes since the moment the church was built until the $20^{\text {th }}$ century. The original church was made of brick in Monk bond and Gothic bond. It consisted of three parts: a squarely closed chancel, nave and extension in the western part - probably of the same size as the chancel.
\end{abstract}


Comparative analysis enabled to date the church for around the half of the $13^{\text {th }}$ century. Later on, in the medieval period, it was reinforced with the buttresses and had the pinnacles rebuilt. The greatest alternations took place in the $18^{\text {th }}$ century. Partly Romanesque walls were then dismantled and the whole church was extended towards the west. Original windows were either bricked up or enlarged. The initial entrance was also bricked up and there was a tower established above the new part of the main frame.

Regardless of the numerous changes, the original form was well preserved as well as the structure of the church, which allowed the reconstruction. Also the analysis of the walls made it possible to follow the $13^{\text {th }}$ century building process. Therefore, the monument possesses great authentic and historical values, especially in terms of recognition of medieval architecture in Greater Poland (Wielkopolska). This was the base for evaluating the elements from the later periods as they should be submitted to conservational protection as well as the initial structure.

\begin{abstract}
Abstrakt
Historia budowlana późnoromańskiego kościoła w Tulcach koło Poznania w świetle badań architektonicznych

Celem niniejszego tekstu jest przedstawienie historii budowlanej późnoromańskiego kościoła w Tulcach w powiecie poznańskim. Nieinwazyjne badania architektoniczne świątyni zostały przeprowadzone w 2014 roku. Ich wyniki skonfrontowano z podstawową literaturą przedmiotu.

$\mathrm{Na}$ tej podstawie udało się wyodrębnić zmiany budowlane wprowadzane od momentu powstania świątyni po XXI wiek. Pierwotny kościół, zbudowany z cegły w wątku wendyjskim i gotyckim, był trójczłonowy, z prosto zamkniętym prezbiterium, nawą oraz dobudówką od zachodu - prawdopodobnie wielkości prezbiterium. Analiza porównawcza pozwoliła datować świątynię na około połowy XIII stulecia. W późniejszym, średniowiecznym okresie kościół wzmocniono szkarpami oraz przebudowano szczyty. Do największych przekształceń doszło w XVIII wieku. Rozebrano wówczas częściowo romańskie mury, wydłużając świątynię w kierunku zachodnim. Zamurowano lub powiększono oryginalne okna, zamurowano pierwotne wejście oraz postawiono wieżę nad nową częścią korpusu.

Mimo licznych przekształceń bardzo dobrze zachowała się oryginalna forma oraz struktura świątyni, co umożliwia jej rekonstrukcję. Analiza murów pozwoliła również na prześledzenie trzynastowiecznego procesu budowlanego. Zabytek ten ma zatem dużą wartość autentyczności oraz historyczną, zwłaszcza dla poznania romańskiego budownictwa Wielkopolski. Rozpoznanie zaś całej historii budowlanej dało podstawę do wartościowania elementów z późniejszych epok, które, tak jak pierwotna struktura, winny podlegać ochronie konserwatorskiej.
\end{abstract}




\section{Wstęp}

Architektura romańska w Polsce jest przedmiotem nieustających dysput naukowych ${ }^{1}$. Główne kierunki badań skupiają się na próbie rekonstrukcji pierwotnego kształtu, układu i konstrukcji tych budowli, ich analizie stylistycznej, szukaniu wzorców i proweniencji. Wobec nielicznych zachowanych źródeł pisanych, nierzadko problematyczne jest dokładne ich datowanie. Znaczna część tych obiektów (zwłaszcza o dużym znaczeniu dla początków państwowości polskiej) została już gruntownie przeanalizowana ${ }^{2}$.

Nie wszystkie zabytki romańszczyzny doczekały się jednak podstawowych w tym zakresie badań: architektonicznych i archeologicznych. Dotyczy to głównie małych wiejskich kościołów ${ }^{3}$. Zdecydowanie mniej uwagi poświęca się również późniejszym ich nawarstwieniom, których rozpoznanie poszerza naszą wiedzę na temat dziejów zabytku, niekończących się wszak w średniowieczu. Wiedza ta jest podstawą prawidłowego zaprogramowania prac konserwatorskich, które poza wydobyciem i uczytelnieniem pierwotnej struktury i formy, winny honorować kolejne zmiany budowlane.

Celem niniejszego tekstu jest prześledzenie historii budowlanej późnoromańskiego kościoła w Tulcach w powiecie poznańskim. Świątynia ta, choć zauważana w literaturze, nie była nigdy przedmiotem szczegółowych analiz ${ }^{4}$; w podstawowych opracowaniach, charakteryzowana jako budowla dwuczło-

1 Zob. podstawową w tym zakresie, wielokrotnie wznawianą pracę: Zygmunt Świechowski, Katalog architektury romańskiej w Polsce (Warszawa: Wydawnictwo DIG, 2009). Zob. też Architektura romańska w Polsce. Bibliografia, oprac. Ewa Świechowska i Wojciech Mischke, wstęp Zygmunt Świechowski (Warszawa: Wydawnictwo DIG, 2001), gdzie wyczerpująca literatura przedmiotu.

2 Szeroki wachlarz nowych, interdyscyplinarnych badań prezentują publikacje wydawnictwa Muzeum Początków Państwa Polskiego w Gnieźnie, zob. Architektura romańska w Polsce. Nowe odkrycia i interpretacje, red. Tomasz Janiak (Gniezno: Muzeum Początków Państwa Polskiego, 2009); Średniowieczna architektura sakralna w Polsce w świetle najnowszych badań, red. Tomasz Janiak i Dariusz Stryniak (Gniezno: Muzeum Początków Państwa Polskiego, 2014); Architektura sakralna w początkach państwa polskiego (X-XIII w.), red. Tomasz Janiak i Dariusz Stryniak (Gniezno: Muzeum Początków Państwa Polskiego, 2016). Spośród opracowań popularnonaukowych zob. Jarosław Jarzewicz, Kościoły romańskie w Polsce (Kraków: Wydawnictwo M, 2014).

3 Jako wyjątek zob. Artur Różański, Jednoprzestrzenne kościoły romańskie z terenu Wielkopolski (Poznań: Wydawnictwo Poznańskie, 2010).

4 W momencie redakcji tego tekstu zostały oddane do druku wyniki badań archeologicznych przeprowadzonych pod koniec 2016 r. przez dr. Artura Różańskiego. 
nowa z prezbiterium i nawą, jest datowana na pierwszą połowę XIII stulecia ${ }^{5}$. Główna uwaga zostanie skupiona na najstarszej fazie budowalnej - wraz z przeanalizowaniem etapowości wznoszenia murów i omówieniem zastosowanej techniki budowlanej - a przyjęte ustalenia wykorzystane do próby hipotetycznej rekonstrukcji pierwotnego wyglądu świątyni. Omówione też będą kolejne jej przekształcenia, aż do czasów współczesnych.

Możliwość poznania zabytku była przede wszystkim uwarunkowana wykonaniem pełnej inwentaryzacji pomiarowo-rysunkowej ${ }^{6}$. Na przygotowanych podkładach piszący te słowa przeprowadzili w 2014 roku badania architektoniczne ${ }^{7}$. Miały one charakter nieinwazyjny, objęły jedynie partie muru z widocznym wątkiem ceglanym (ściany zewnętrzne prezbiterium i nawy wraz ze szczytami). Ich wyniki zostały skonfrontowane z dostępnymi danymi historycznymi.

Przyjęta metoda badawcza polegała na analizie tzw. węzłów badawczych, styków murów, pomiarze cegieł, optycznej charakterystyce zaprawy oraz sposobu opracowania spoiny, rejestracji i określeniu cech detali architektonicznych, opraw otworów okiennych, wypraw tynkarskich i ewentualnych pobiał.

Autorzy składają podziękowania Panu mgr. Adamowi Kazimierczakowi za bezinteresowną opiekę nad właściwym przebiegiem wszelkich prac po-

5 Katalog zabytków sztuki w Polsce, t. 5 Województwo poznańskie, red. Teresa Ruszczyńska i Aniela Sławska, z. 24 Powiat średzki, oprac. Teresa Ruszczyńska i Aniela Sławska (Warszawa: Instytut Sztuki PAN. Pracownia Inwentaryzacji Zabytków, 1964), 27; Świechowski, Katalog, 553-554; takie datowanie jest podawane także w starszych wydaniach książki Świechowskiego. Janusz Tomala wymienia również 1263 r. (lecz bez odniesienia do źródła), przy czym w katalogu tej samej pracy brak owej daty, a czas budowy jest przesunięty na koniec XIII lub przełom XIII i XIV w. Zob. Janusz Tomala, Murowana architektura romańska i gotycka $w$ Wielkopolsce, t. 1 Architektura sakralna (Kalisz: Edytor - Sławomir Woźniak, 2007), 56, 430; Janusz Tomala, Architektura gotycka Wielkopolski (Kalisz: Edytor - Sławomir Woźniak, 2013), 27. Zob. też Paweł Filipowicz, Leszek Kajzer i Zbigniew Lechowicz, „Późnoromański, ceglany kościół w Strońsku nad Wartą w świetle najnowszych badań”, w Architektura romańska w Polsce. Nowe odkrycia, 480. Bardziej ogólne opracowanie zob. Jacek Kowalski, „Großpolen”, w Mittelalterliche Architektur in Polen. Romanische und gotische Baukunst zwischen Oder und Weichsel, Bd. 1, Hg. Christofer Herrmann i Dethard von Winterfeld (Petersberg: Michael Imhof Verlag, 2015), 282.

6 Inwentaryzacja pomiarowo-rysunkowa została sporządzona w 2014 r. przez studentów kierunku ochrona dóbr kultury, specjalność konserwatorstwo, UMK w Toruniu w składzie: Dominika Karbownik, Adam Kaźmierczak, Tomasz Kowalski, Anna Patelka, Monika Rogalewska, Joanna Szymczak.

7 Karolina Zimna-Kawecka i Maciej Prarat, „Projekt konserwatorski: Badania architektoniczne kościoła p.w. Narodzenia Najświętszej Marii Panny w Tulcach (pow. średzki)” (dokumentacja konserwatorska, Tulce 2014, Archiwum parafii w Tulcach). 
dejmowanych przy kościele w Tulcach oraz Panu dr. Arturowi Różańskiemu z Uniwersytetu Poznańskiego za inspirującą wymianę poglądów.

\section{Historia kościoła}

Jedyne znane dotąd przekazy o początkach kościoła w Tulcach pochodzą z czasów późniejszych niż hipotetyczna data powstania zabytku. Publikowane źródła podają, że świątynia, pierwotnie drewniana, powstała około 1140 roku, a jej fundatorem był Piotr Dunin ze Skrzynna - rycerz Bolesława Krzywoustego. Pierwsza wzmianka o obecnym budynku pochodzi z 1363 $\mathrm{roku}^{8}$. Kolejna informacja o murowanym „gotyckim” kościele została zapisana w Liber beneficiorum dioecesis Posnaniensis z roku 1510. W tym czasie wieś Tulce należała do wielkopolskiej możnowładczej rodziny Górków. Kasztelan poznański, starosta wielkopolski i biskup kujawski Łukasz Górka w 1529 roku przyłączył kościół parafialny do kolegium mansjonarzy w Kórniku9. W roku 1593, po latach patronatu protestanckich przedstawicieli rodu Górków, katolicy odzyskali swój dawny kościół - był wtedy zaniedbany (a wraz z nim zabudowania probostwa), o czym wspominały wizytacje jeszcze w 1629 i 1639 $\mathrm{roku}^{10}$.

W początkach XVII wieku kościół w Tulcach, który składał się wówczas z korpusu nawowego i niższego prezbiterium, odzyskał status parafialnego ${ }^{11}$. W 1662 roku, po wcześniejszym odnowieniu wnętrza, poświęcono główny oł-

8 Informację tę podaje Julius Kohte za Codex diplomaticus Majoris Polonia documenta, et jam typis descripta, et adhuc inedita complectens, annum 1400 attingentia, wyd. Ignacy Zakrzewski, t. 3 (Poznań: Biblioteka Kórnicka 1879), nr 1496. Zob. Julius Kohte, Verzeichnis der Kunstdenkmäler der Provinz Posen, Bd. 3 Die Landkreise des Regierungsbezirks Posen, Lieferung 4 (Berlin: Verlag von Julius Springer, 1896), 288. Por. Pamiątka z Tulec, oprac. Mieczysław Noskowicz (Poznań: M. Noskowicz i Spł., 1917), 19.

9 Łukasz Górka był dziedzicem Tulec w latach 1513-1538, w związku z tym niektórzy autorzy datowali kościół na I poł. XVI w. Zob. Józef Łukaszewicz, Krótki opis historyczny kościołów parochialnych, kościółków, kaplic, klasztorów, szkółek parochialnych, szpitali i innych zakładów dobroczynnych $w$ dawnej dyecezyi poznańskiej, t. 1 (Poznań: Księgarnia Jana Konstantego Żupańskiego, 1858), 341-342; „Cudowny obraz Matki Boskiej w Tulcach”, Album Przewodnika Katolickiego 2 (1908): 15. Podjęto wtedy nie budowę, lecz generalny remont/przebudowę świątyni. Z tego czasu, według późniejszych badaczy, mają pochodzić szkarpy. Zob. Katalog zabytków, 27-28.

10 Jacek Wnęk, „Kult Matki Bożej Tuleckiej” (praca magisterska, Wydział Teologiczny Katolickiego Uniwersytetu Lubelskiego, 1983), 9 (na podstawie dokumentów wizytacji przechowywanych w Archiwum Diecezjalnym w Poznaniu).

11 Zgodnie z księgą wizytacji bp. Strzałkowskiego z 1628 r. Zob. Pamiątka z Tulec, 20; Łukaszewicz, Krótki opis, 342. 
$\operatorname{tarz}^{12}$. W takim kształcie świątynia funkcjonowała do rozbudowy w roku 1784. Przedłużono wtedy nawę, postawiono wieżę, obie części - starą wschodnią i nową zachodnią - przekryto stropem, w prezbiterium wprowadzono łuk tęczowy, a między korpusami arkadę, przebudowano też okna i otynkowano gzymsy wieńczące ${ }^{13}$. Na początku XX wieku dostawiono zakrystię i kruchtę boczną ${ }^{14}$. Około 1917 roku kościół, cztery lata wcześniej odnowiony, był w dobrym stanie. Na polichromowanym stropie z podsufitką w części wschodniej korpusu widniało wyobrażenie Chrystusa Zbawiciela, w części zachodniej zaś Matki Boskiej jako Królowej Aniołów. Inskrypcje sporządzone na polach tynkowych szczytów od wnętrza oraz na ścianie południowej prezbiterium pod dachem zakrystii informują, że w 1926 r. uzupełniono (lub wymieniono w całości na nową) dachówkę nad nawą i prezbiterium; w 1931 r. przeprowadzono prace remontowe (lub wymianę) dachu nad zakrystią; w $1937 \mathrm{r}$. wykonano prace dekarskie nad nawą oraz prawdopodobnie naprawy szczytu zachodniego.

Z dokumentacji przechowywanej w archiwum parafii wynika, że w 1948 roku kościół odmalowano. W drugiej połowie XX wieku systematycznie wykonywano remonty i prace naprawcze. Do ważniejszych należały: wymiana okien, posadzki, a w latach 1993-1995 kompletna wymiana osiemnastowiecznej konstrukcji wieży, więźby dachowej i stropów ${ }^{15}$.

\section{Opis kościoła}

Kościół w Tulcach jest orientowany, murowany z cegły, jednonawowy, z przedłużoną w wyniku dobudowy, dwuczłonową nawą (część zachodnia nieco węższa), z prostokątnym prezbiterium oraz drewnianą wieżą od strony zachodniej, nadbudowaną nad korpusem i stykającą się z fasadą (il. 1, 4). Od północy do prezbiterium przylega zakrystia na planie kwadratu, a od południa do nowszej części korpusu - kruchta boczna, również na rzucie kwadratu. Ściany części wschodniej korpusu i prezbiterium od strony południowej

12 Pamiątka z Tulec, 42; Wnęk, „Kult Matki Bożej”, 9.

13 Pamiątka z Tulec, 20-21; Katalog zabytków, 27-28.

14 Katalog zabytków, 27-28; „Parafia Narodzenia NMP w Tulcach”, Dostęp 12 czerwca 2014, http://tulce.archpoznan.pl/historia.

15 „Parafia Narodzenia NMP w Tulcach”, Dostęp 12 czerwca 2014; „Kościół p.w. Narodzenia NMP, Tulce”, „Karta Ewidencyjna Zabytków Architektury i Budownictwa”, oprac. M. Jarzewicz (dokumentacja ewidencyjna, Tulce 1987, Archiwum Wojewódzkiego Urzędu Ochrony Zabytków w Poznaniu); dokumentacja z Archiwum Parafialnego w Tulcach. 
zostały oszkarpowane masywnymi, uskokowymi przyporami. Część zachodnią korpusu otynkowano, podobnie jak ściany wewnątrz oraz przybudówki.

Nawę, prezbiterium i kruchtę boczną nakryto (każdy człon oddzielnie) dwuspadowymi dachami, zakrystię zaś trójspadowym dachem z ceramicznej dachówki karpiówki. Wieżę wzniesioną w konstrukcji szkieletowej oszalowano i nakryto miedzianym baniastym hełmem o formie barokowej.

Dwukondygnacyjna, trójosiowa fasada (il. 3) ma wyodrębnioną strefę cokołową i attykowy szczyt. W dolnej części jest artykułowana po bokach zdwojonymi pilastrami, nałożonymi jeden na drugi. Na osi środkowej znajduje się zamknięty półkoliście portal zwieńczony uproszczoną formą wimpergi w formie łuku namiotowego. Obie strony wejścia zdobią prostokątne blendy. Wyżej, na trzech osiach, umieszczono blendy zamknięte łukiem odcinkowym.

Szczyt od ściany oddziela profilowany gzyms, gierowany przy narożach. Ściankę attykową ujęto po bokach w dolnej części w spływy wolutowe biegnące pionowo w dół, z wywiniętymi tylko głowicami wolut. Pole wypełniono podwójnymi pilastrami, a na osi środkowej usytuowano na profilowanym gzymsie prostokątną niszę z figurą Matki Boskiej, otoczoną tynkowaną opaską. Taką samą tynkowaną opaską wydzielono pod i nad blendą prostokątne płyciny (górna ze ściętymi łukowo narożnikami). Całość zwieńczono profilowanym gzymsem i trójkątnym naczółkiem, obwiedzionym podobnym profilowaniem.

Wyżej wznosi się drewniana elewacja wieży, zakończona wydatnym gzymsem z półkolistym wycięciem multiplikowanym w połaci przekrycia. Hełm wieży zakończono wieloboczną, ażurową latarnią zwieńczoną kulą z krzyżem. Wszystkie ściany wieży wyglądają jednakowo.

Południowa elewacja korpusu (il. 2) jest złożona z dwóch członów. Część zachodnia, dwuosiowa, z dwoma oknami zamkniętymi łukiem odcinkowym, została częściowo przysłonięta parterową dobudówką kruchty zwieńczonej trójkątnym szczytem. Ścianę tę zakończono profilowanym gzymsem. Między częścią zachodnią a wschodnią znajduje się trójskokowa masywna ceglana szkarpa z wyodrębnioną strefą cokołową z wałkowym profilem. W części wschodniej (il. 5), również dwuosiowej, u dołu jest widoczny zamurowany otwór wejściowy zamknięty półkolistym łukiem. Wyżej, na osiach, dwa otwory okienne zakończone łukiem odcinkowym są ujęte w tynkowane opaski, łączące się u góry z pasem tynkowanego fryzu i profilowanym gzymsem. Od wschodu do tej części przylega ceglana ściana prezbiterium z południowo-wschodnim narożnikiem wzmocnionym masywną, dwuuskokową szkar- 
pą. Elewacja prezbiterium ma jedno zamknięte pełnym łukiem okno, ujęte w tynkowaną opaskę, taką samą jak w nawie, i identyczny fryz z gzymsem.

Na elewacji północnej korpusu (il. 4) część wschodnia jest rozwiązana podobnie jak w elewacji południowej (bez wejścia). Między oknami na osi widać zamurowany otwór okienny zamknięty półkoliście. Narożnik przy części zachodniej wzmacnia szkarpa, taka jak po stronie południowej, ale z cokołem zakończonym układem rolkowym. Część zachodnia elewacji, dwuosiowa, ma okna usytuowane identycznie jak po stronie południowej. Od wschodu przylega do niej ceglana ściana prezbiterium, pozbawiona otworów, przysłonięta w większości przez parterową zakrystię. W tej części są również - przesunięte z osi środkowej w kierunku zachodnim - drzwi zamknięte łukiem odcinkowym, a na osi środkowej eliptyczny okulus. Analogiczne okna znajdują się w ścianie zachodniej i krótkiej ściance południowej, natomiast ściana wschodnia ma duże prostokątne okno sięgające wysokości profilowanego gzymsu, biegnącego wokół wszystkich ścian przybudówki.

Elewacja wschodnia prezbiterium (il. 6) została zakończona trójkątnym szczytem z prostokątnymi filarkowymi konsolami na narożach, z przesklepioną półkoliście ediculą w górnej części, gdzie umieszczono figurę Matki Boskiej. Krawędź szczytu zaakcentowano ceglanym fryzem w układzie rolkowym. Nad szczytem widać ścianę wschodniego ceglanego szczytu korpusu, z narożnymi filarkami u nasady, wspartymi na ceglanych uskokowych wspornikach. Przy narożu południowym znajduje się szkarpa, a po stronie północnej zakrystia, w nieznacznym stopniu zachodząca na elewację ${ }^{16}$.

Jednonawowe wnętrze składa się z dwóch części przedzielonych półkolistą arkadą, wspartą na przyściennych pilastrach o profilowanych narożach, z podłuczem ozdobionym prostokątnymi wydłużonymi pseudokasetonami. W południowo-zachodnim narożniku części zachodniej umieszczono schody na nadwieszoną emporę, a w ścianie południowej rozglifione wejście do kruchty. W ścianach północnej i południowej, bliżej arkady międzynawowej, znajdują się przesklepione odcinkowym łukiem wnęki, w których ustawiono konfesjonały. Na linii balustrady empory metalowa krata spełnia funkcję podpory chóru muzycznego.

Prezbiterium jest oddzielone od nawy, podobnie jak korpusy, półkolistą arkadą łuku tęczowego. W jego północnej ścianie wybito wejście do zakrystii.

16 W korpusie w rozglifionych otworach zamontowano współczesną metalową stolarkę okienną. Stolarka drzwiowa jest drewniana. 
Wewnątrz kościoła kamienne posadzki są ułożone w szachownicę. Wprowadzone stropy Kleina z podsufitką zdobią fasety i sztukaterie geometryczne tworzące prostokątne ramy z metalowymi ażurowymi rozetami, przysłaniającymi otwory wentylacyjne. Na emporę z drewnianą balustradą $\mathrm{w}$ konstrukcji ramowo-płycinowej prowadzą drewniane, jednobiegowe policzkowe schody łamane z zakrętem ${ }^{17}$.

Niszę we wschodniej ścianie prezbiterium przysłania ołtarz główny. Jego nastawa, w formie barokowej, została wykonana około 1730 roku. Stojąca na ołtarzu drewniana gotycka figura Matki Boskiej z Dzieciątkiem jest datowana na lata około 1500. Pozostałe wyposażenie kościoła pochodzi z przełomu $\mathrm{XV} / \mathrm{XVI}$ stulecia oraz z okresu baroku ${ }^{18}$.

\section{Rozwarstwienie chronologiczne}

W wyniku przeprowadzonych badań architektonicznych kościoła w Tulcach wyodrębniono pięć faz budowlanych z piętnastoma etapami, odpowiednio do dotychczasowego stanu wiedzy (il. 1, 2, 3).

\section{Faza I}

(późnoromańska: połowa XIII w. - druga połowa XIII w.)

Najstarsza, wschodnia część korpusu z prezbiterium wykazuje jednolity charakter i powstała w obrębie jednej fazy budowlanej, choć podzielonej na kilka etapów. Najpierw wymurowano strefę cokołową prezbiterium i korpusu, prawdopodobnie stawiając mury z obu stron jednocześnie (il. 5: a; il. 6: a). Następnie wzniesiono ścianę północną i wschodnią korpusu (il. 4: b) oraz wschodnią, północną i południową prezbiterium do poziomu warstwy wyrównującej (il. 6: b). Budowę kontynuowano w kierunku zachodnim, podnosząc ścianę południową nawy do tej samej wysokości. Później wymurowano ściany prezbiterium do nasady szczytu (il. 6: c).

W ostatnim etapie pierwszej fazy wzniesiono szczyt prezbiterium i nawy z przejściami między prezbiterium a nawą oraz nawą a kolejnym, nieistniejącym dziś członem budynku (il. 7). Szczyt prezbiterium zbudowano z dwóch równoległych nieprzewiązanych murów, w górnej części wymurowano prze-

\footnotetext{
17 Wnętrze zakrystii jednoprzestrzenne ze ściętymi trzema narożnikami - w południowo-wschodnim narożniku znajduje się wnęka okienna z eliptycznym okulusem.

18 Katalog zabytków, 28.
} 
świt wentylacyjny, a w dolnej otwór doświetlający wnętrze - prawdopodobnie przesklepione pozorną kolebką.

Mury prezbiterium wzniesiono w wątku wendyjskim, dwuwozówkowym, miejscami trójwozówkowym. Wątek ten przemieszany jest z wątkiem gotyckim miejscowo w obrębie danej warstwy. Cegły siedmiu warstw w strefie cokołowej ściany wschodniej - licząc od przyziemia w górę - mają większe wymiary, podobnie jak cegły w ośmiu warstwach strefy cokołowej ściany południowej i północnej $(13 / 29 / 10 \mathrm{~cm}, 5 \mathrm{w}=60 \mathrm{~cm})$. Cegły wyższych warstw są nieco niższe $(13 / 27 / 8,5 \mathrm{~cm}, 5 \mathrm{w}=51-52 \mathrm{~cm})$. W ścianie wschodniej na wysokości dwudziestu pięciu warstw cegieł, od strony północnej biegnie w kierunku osi środkowej ukośnie ścięta, cienka (około 1/2-2/3 normalnej wysokości) warstwa wyrównująca cegieł (il. 6: f) ${ }^{19}$. Podobna warstwa wyrównująca jest widoczna na ścianie południowej. Wyżej wielkość cegieł nie zmieniła się. Miejscowo zachowała się oryginalna spoina: o profilu wałkowym lub trójkątnym, podcinana wzdłużnie podwójnie, przy górnej i dolnej krawędzi.

Ściana wschodnia nawy rozwiązana została w wątku głównie gotyckim, w wyższych partiach mieszanym z wendyjskim. Cegły w ośmiu dolnych warstwach są wyższe, tak jak w przewiązanych z nimi murach prezbiterium. Wyprowadzenie narożnika południowego jest nieco inne niż w prezbiterium ${ }^{20}$. Ściana południowa została wzniesiona w wątku wendyjskim dwu- i trójwozówkowym oraz nieregularnym z elementami gotyckiego, zwłaszcza w części przyziemia. W wyższych partiach również wykorzystano cegły, zaprawę i spoinowanie podobne do pozostałych murów części wschodniej i prezbiterium. W ścianie północnej jedyna różnica występuje w miejscu wyrównania: dwudziesta szósta warstwa cegieł jest ścięta ukośnie w kierunku wschodnim (il. 4: f) i pełni funkcję wyrównującą podobnie do odpowiednich warstw w omówionych ścianach prezbiterium. Ustalenia te wskazują, że wznosząc wschodnią część budowli najprawdopodobniej wyprowadzano mury jednocześnie z dwóch narożników, a następnie na widocznej do dzisiaj wysokości wyrównano poziomy.

19 Rozpościera się ona na około 1/3 szerokości ściany. Nad nią znajduje się właściwa warstwa cegieł. Obie są kontynuowane w kierunku południowym przez warstwę cegieł ułożonych blatem do lica, w wątku „główkowo-wozówkowym”. W pobliżu południowego skraju ściany cegły ułożono już wozówką do lica. Wizualnie zatem warstwa wyrównująca biegnie ukośnie w dół.

20 W prezbiterium układ warstw jest naprzemienny: główka(g)-wozówka(w)-rzemyk/beleczka(r); w-w-g lub -r. Układ cegieł narożnika ściany korpusu: g-w-w lub -g; w-w-g lub w-r(g)-w. 
Mury nawy zakończone są od wschodu i zachodu uskokami z ukośnym biegiem krawędzi, co sugeruje, że miały one wzmacniać ściany pozbawione pierwotnie przypór. Ślad po pierwotnym, zamurowanym otworze okiennym w północnej ścianie wschodniej części korpusu wykazuje pod względem formy analogię do zamurowanego otworu w północnej ścianie prezbiterium, obecnie ukrytego pod dachem zakrystii. Południowe okno w prezbiterium zachowuje jeszcze okrągły łuk, a między południowymi oknami nawy znajduje się przemurowany fragment - również w miejscu dawnego otworu (il. 5: d). W osi zachodniej tej ściany widać zamurowany pierwotny portal (il. 5: e).

Pierwotna forma okna zachowała się też na wschodniej ścianie prezbiterium - otwór zamurowano pozostawiając blendę (il. 6: d).

Niezwykle interesująco przedstawia się zachodni szczyt starszej części nawy (il. 7). Po pierwsze, ma on przejście w kierunku zachodnim, co sugeruje trzeci człon świątyni. Po drugie, na jego murze od strony zachodniej (obecnie nowsza część korpusu) widoczny jest zarys starszego, niższego trójkąta (ślad zaprawy i przybrudzenie cegieł), którego wysokość odpowiada wysokości dachu prezbiterium ${ }^{21}$. Nie ma pewności, czy jest to ślad pierwotny, czy związany z późniejszymi przebudowami. Jednak brak opracowania spoiny poza obrębem śladu trójkąta (pierwotnego poddasza) może świadczyć, że już wznosząc szczyt przewidziano taką wysokość dachu dla trzeciego członu budowli (il. 8$)^{22}$.

\section{Rekonstrukcja wyglądu i datowanie świątyni}

Pierwotny kościół złożony był zatem z trzech członów: prezbiterium, nawy i obiektu po stronie zachodniej, o wysokości zbliżonej do prezbiterium (il. 9) ${ }^{23}$. W części tej być może znajdowała się empora. Mury korpusu przepruto z dwóch stron trzema oknami zamkniętymi półkolistym łukiem ${ }^{24}$, a w ścia-

${ }^{21}$ Siedemnaście warstw powyżej otworu wejściowego.

22 W przestrzeni „pierwotnego” poddasza spoina jest opracowana przez podcięcie z dwóch stron. Ponieważ jest to dość znaczna wysokość, najprawdopodobniej budowniczowie nie widzieli potrzeby spoinowania niewidocznej z bliska partii ściany poza jego obrębem (co nie było jednak normą).

${ }_{23} \mathrm{~W}$ artykule nie jest poruszana problematyka pierwotnej funkcji tej części, której rzut, według najnowszych badań dr. A. Różańskiego, odpowiada rozmiarom prezbiterium. Zob. przyp. 4 .

24 Zachowane jest tylko środkowe okno w elewacji północnej, w południowej zaś przemurowany po nim ślad. Brak jednoznacznych dowodów na obecność pierwotnych okien po bokach. Logika budowlana pozwala przypuszczać, że dzisiejsze okna najprawdopodobniej wyprowadzono rozkuwając wcześniejsze mniejsze otwory boczne. 
nie południowej wybito główne wejście. Prezbiterium z każdej strony miało pojedyncze okno - analogicznie do nawy. Wnętrze prezbiterium mogło być przesklepione drewnianą kolebką. Duży otwór widoczny w wewnętrznym murze wschodniego szczytu jest najprawdopodobniej poszerzeniem wcześniejszego, mniejszego. Nie wiadomo, jak wyglądało przejście z prezbiterium do nawy. Obecna arkada jest prawdopodobnie elementem wtórnym, pochodzącym z kolejnej fazy budowy, ponadto jej forma sugeruje, że mogła też powstać razem z rozbudową kościoła. Z kolei mury trzeciego członu pierwotnego założenia mogły zostać częściowo wykorzystane podczas rozbudowy korpusu.

Datowanie I fazy budowlanej na obecnym etapie rozpoznania należy oprzeć na konfrontacji wyników badań architektonicznych w Tulcach z danymi dotyczącymi innych obiektów późnoromańskiej architektury sakralnej w Polsce. Przeprowadzona w ten sposób analiza porównawcza daje podstawy do założenia, że omawiany kościół mógł powstać około połowy XIII wieku bądź w drugiej połowie tego stulecia.

Wiek XIII był okresem intensywnego rozwoju budownictwa sakralnego, któremu towarzyszyło upowszechnienie cegły - wcześniej jako budulca używano kamienia ${ }^{25}$. Zagęściła się sieć kościołów parafialnych, stawiano je bowiem także poza największymi ośrodkami. Najczęściej były to budowle jednonawowe, z wyodrębnionym prezbiterium, które od drugiej ćwierci XIII w. zamiast absydą zamykano prostą ścianą ${ }^{26}$. To zakończenie jest charakterystyczne dla późnoromańskiej architektury w różnych regionach, przykładem są między innymi kościoły w Starym Mieście (pow. koniński), w Czerwonej Wsi (pow. kościański), w Krzyworzece (pow. wieluński), w Sławkowie (pow. będziński ${ }^{27}$. W XIII wieku nadal powszechnie stosowano w nawach płaskie przekrycia stropem, ale w prezbiterium często zakładano sklepienie krzy-

25 Zygmunt Świechowski, Architektura romańska w Polsce (Warszawa: Wydawnictwo DIG, 2000), 26; Jan Zachwatowicz, „Architektura”, w Sztuka polska przedromańska i romańska do schyłku XIII wieku, red. Michał Walicki, seria: Dzieje sztuki polskiej, red. Michał Walicki et al., t. 1 (Warszawa: Państwowe Wydawnictwo Naukowe, 1971), 149.

26 Półokrągłe absydy utrzymały się do II poł. XIII w. Zob. Świechowski, Architektura, 29; Zachwatowicz, „Architektura”, 161, 163; Witold Krassowski, Dzieje budownictwa i architektury na ziemiach Polski, t. 2 (Warszawa: Arkady, 1990), 56. Dla terenów Wielkopolski z tzw. okresu przejściowego, w którym J. Tomala umieścił kościół w Tulcach, autor wymienia jednonawowe świątynie z prosto zamkniętym prezbiterium w 16 miejscowościach. Zob. Tomala, Murowana architektura, 60.

27 Zachwatowicz, „Architektura”, 165. Kościół w Tulcach wymienia też wśród XIII-wiecznych świątyń w Wielkopolsce Kowalski, „Großpolen“, 282. 
żowo-żebrowe ${ }^{28}$. Innym rozwiązaniem przyjmowanym w prezbiterium było sklepienie pozorne - o takim przekryciu świadczyło wprowadzenie otworów okiennych w strefy szczytów (np. w kościele św. Jana Jerozolimskiego w Poznaniu $)^{29}$. Ślad po oknie w szczycie świątyni w Tulcach wskazuje, że prezbiterium miało ten rodzaj sklepienia.

Odpowiednikiem hipotetycznej rekonstrukcji pierwotnej świątyni w Tulcach - budowli z prosto zamkniętym prezbiterium, artykulacją nawy trzema oknami i kolejnym członem od zachodu - jest ceglany kościół w Rokiciu (pow. płocki), datowany na połowę XIII wieku. Jego mury również mają wątek mieszany, wendyjski i gotycki ${ }^{30}$. Podobnie przedstawia się kościół w Strońsku nad Wartą - w wyniku badań architektoniczno-archeologicznych został zrekonstruowany jako jednonawowy budynek z wyodrębnionym prezbiterium zamkniętym absydą, od zachodu zaś z masywem dwuwieżowym i emporą, mający po trzy okna w ścianach wzdłużnych nawy, wymurowany z cegły w wątku wendyjskim i gotyckim, a datowany na lata około 1235-124731.

Większość świątyń z około połowy XIII wieku ma korpus doświetlony w każdej ze ścian dwoma lub jednym oknem. Po trzy otwory okienne zastosowano, poza omówionymi obiektami, na przykład w kamiennym kościele w Tarczku (pow. starachowicki) pochodzącym z drugiej ćwierci XIII w., we Włostowie (pow. opatowski) z połowy tego stulecia, w kamienno-ceglanej świątyni w Gardnie (pow. gryfiński) datowanej na pierwszą połowę XIII wieku. Jednak w tych budynkach portale znajdują się mniej więcej na osiach środkowych bocznych ścian nawy. Natomiast w Tulcach, Rokiciu, Strońsku portal jest przesunięty na oś boczną. Zbliżone rozwiązanie - z niewielkim

28 Zachwatowicz, „Architektura”, 192.

29 Krassowski, Dzieje, 57-58; Świechowski, Architektura, 200-201.

30 Andrzej Tomaszewski, Romańskie kościoły z emporami zachodnimi na obszarze Polski, Czech i Węgier (Wrocław: Ossolineum, 1974), 168-169; Artur Wołosz, „Romański kościół p.w. św. Małgorzaty w Rokiciu”, Notatki Płockie 34 (1989): 17-24.

31 Filipowicz, Kajzer i Lechowicz, „Późnoromański, ceglany kościół”, 478. Zob. też Paweł Filipowicz, Leszek Kajzer i Zbigniew Lechowicz, „Późnoromański kościół p.w. św. Urszuli i Jedenastu Tysięcy Dziewic w Strońsku nad Wartą. Interwencyjne badania architektoniczne w latach 2005-2006”, Ochrona Zabytków 4 (2006): 5-22. Trzy okna w nawie można odnaleźć również np. w kamiennym (ob. otynkowany) czeskim kościółku w miejscowości Stará Boleslav, datowanym nawet na połowę XII w. Zob. Artur Różański, „Czeskie i morawskie wzorce architektoniczne na terenie ziem polskich we wczesnym średniowieczu. Fakty i mity”, Archeologia Historica Polona 21 (2013): 40, ryc. 4. 
przesunięciem wejścia w stronę osi bocznej - występuje w Gieczu (pow. średzki $)^{32}$.

Z kolei wiele późnoromańskich kościołów z pierwszej połowy XIII wieku ma podobny do tuleckiego układ prezbiterium z oknami w każdej ze ścian - na przykład wspomniana świątynia w Poznaniu z połowy stulecia, ceglany kościół z lat trzydziestych w Czerwonej Wsi (pow. kościański), kamienny w Dziekanowicach (pow. myślenicki), obiekty w Mieronicach (pow. jędrzejowski) i w Starym Mieście (pow. koniński) ${ }^{33}$.

Komunikację w partii poddasza między trzema członami budynku zapewniały przejścia w obu szczytach na wysokości więźby. W Tulcach przesklepiono je łukiem zbliżonym do odcinkowego, jednak obecnie wykonanym w cegle maszynowej, jako rekonstrukcja. Nie wiadomo zatem, jaka dokładnie była ich pierwotna forma. Łuki odcinkowe w mniej eksponowanych miejscach są w czternastowiecznej architekturze powszechnie znane. Wnęki przejść wykonano jednak razem ze szczytami, które wykazują konstrukcyjne i materiałowe analogie ze ścianami korpusu.

Większość kościołów z okresu późnoromańskiego nie ma też w pełni wykształconych, narożnych przypór, co dodatkowo potwierdza, że w Tulcach mogły one zostać dobudowane w II fazie, którą należy łączyć z przebudową zleconą przez Łukasza Górkę 34 .

Układy z połowy XIII wieku są ponadto pozbawione zakrystii. Wprawdzie w kościele w Kępnicy (pow. nyski), a także w Tymowie (pow. lubiński), w ścianie prezbiterium znajduje się otwór wejściowy sugerujący istnienie takiej dobudówki, lecz może on pochodzić z późniejszej fazy budowlanej ${ }^{35}$.

Faza II

(gotycko-nowożytna: pierwsza ćwierć XVI w. - druga połowa XVII w.)

Kolejną fazę budowlaną i jej przyczyny należy łączyć z widocznymi na murach pionowymi pęknięciami i zwichrowaniami lica najstarszej części budowli - zwłaszcza na ścianie północnej i południowej korpusu. Spowodowała je

32 Ceglaną romańską świątynią (zrekonstrowaną) o 3 oknach w ścianie południowej jest też kościół w Inowłodzu. Zob. Świechowski, Architektura, 56-57; Zachwatowicz, „Architektura”, 192.

33 Świechowski, Architektura, 225-226. Świątynie w Poznaniu, Czerwonej Wsi i Dziekanowicach zostały w okresie nowożytnym rozbudowane, podobnie jak w Tulcach, w kierunku zachodnim. Zob. Świechowski, Architektura, 52-53.

34 W Kiełczynie narożną przyporę przy prezbiterium uznano za dostawioną, podobnie jak w Starym Mieście. Zob. Świechowski, Architektura, 96, 225-226.

35 Świechowski, Architektura, 94, 266. 
zapewne niestabilność gruntu lub fundamentów. Próbowano temu zaradzić dostawiając szkarpy, a w kolejnych latach wzmacniając je obmurowaniem.

Faza II dzieli się na dwa zasadnicze etapy, z których pierwszy datować można zgodnie z przekazami o „budowie” lub przebudowie kościoła przez Łukasza Górkę między rokiem 1513 a 1538. Dodatkowo o remoncie może świadczyć ufundowanie w 1536 roku dzwonu do drewnianej dzwonnicy. W jakimś zakresie wnętrze kościoła musiało być też odnowione około 1593 roku, kiedy przekazano go ponownie katolikom ${ }^{36}$.

Ze względu na wymianę więźby i brak udokumentowania poprzedniej jej konstrukcji nie sposób odnieść się do innych elementów przebudowy - na przykład podwyższenia ze zmianą spadku linii dachowej szczytów. Narożne sterczynowe filarki, znane z fasad wielu gotyckich kościołów, sugerują przyporządkowanie ich do II fazy obejmującej okres późnego gotyku. Być może w tym samym czasie w podwyższonych szczytach wymurowano okrągłe otwory wentylacyjne.

Niewykluczone, że jakieś prace należy wiązać z drugą połową XVII wieku. Kościół był ponownie użytkowany przez katolików, a w wizytacjach z pierwszej połowy stulecia. wskazuje się na zaniedbanie świątyni i zabudowań probostwa. Uwieńczeniem ówczesnych napraw mogło być poświęcenie w 1662 roku głównego ołtarza oraz ufundowanie siedem lat później drugiego dzwonu. Wiadomo też między innymi, że w 1681 roku kasztelan Wojciech Czacki ustanowił osobne uposażenie dla „wielkiego ołtarza” ${ }^{37}$. W tym czasie kościół składał się z nawy i prezbiterium, zatem na pewno nie posiadał wieży38.

Możliwe jednak, że drugi etap fazy II przebudowy należałoby umieścić między drugą połową XVII wieku a pierwszą ćwiercią następnego stulecia między innymi z tego względu, że na lata trzydzieste XVIII wieku datowany jest obecny ołtarz główny. W związku z budową nowego ołtarza musiano zamurować otwór okienny w ścianie wschodniej prezbiterium, przysłonięty przez retabulum. Wykonano wtedy wnękę poniżej okna, w której umieszczono wizerunek Najświętszej Marii Panny ${ }^{39}$ - wizytacja z 1639 roku nazywa już figurę „cudowną”, zatem na pewno potrzebowała odpowiedniego wyekspo-

36 Katalog zabytków, 27-28; Łukaszewicz, Krótki opis, 342; Pamiątka z Tulec, 27.

37 „Parafia Narodzenia NMP w Tulcach”, Dostęp 12 czerwca 2014.

38 Pamiątka z Tulec, 20, 27, 42; Wnęk, „Kult Matki Bożej”, 9; Łukaszewicz, Krótki opis, 342.

39 Badania architektoniczne przewiązania wnęki z murami były niemożliwe z powodu braku dostępu. 
nowania ${ }^{40}$. Zamurowanie okna mogło też wywołać konieczność dodatkowego doświetlenia prezbiterium. W tym celu zapewne poszerzono przez rozkucie otwór okienny/wentylacyjny w dolnej części szczytu oraz powiększono na wysokość okno w ścianie południowej (widoczne zamurowanie z późniejszej fazy budowlanej; il. 1).

\section{Faza III}

(nowożytna: około 1784 r. do początku XIX w.)

Faza III przekształceń budowlanych związana jest z rozbudową kościoła w 1784 roku, polegającą na dostawieniu obecnej części zachodniej nawy. W związku z tym zdecydowano się na zamurowanie okien w osiach środkowych wcześniejszych murów. Ich likwidacja miała też przyczyny estetyczno-praktyczne - pozostałe bowiem okna powiększono, doświetlając odpowiednio wnętrze i ujednolicając ich formę z nową częścią. W tym samym czasie zamurowano portal w ścianie południowej. Niewykluczone, że w tej samej fazie dobudowano zakrystię, a w kolejnym etapie - kruchtę $e^{41}$.

Ślady na szczycie zachodnim dobudowanej części sugerują, że pierwotna koncepcja różniła się od znanej, obecnie zrekonstruowanej - wieża była mniejsza i nie przylegała do muru (mogła mieć postać większej sygnaturki). Świadczą o tym ślady odcisku zaprawy po wcześniejszej konstrukcji dachu na murze obecnego zachodniego szczytu (il. 10) ${ }^{42}$.

Wieża w obecnej formie powstała w kolejnym etapie razem z podniesieniem muru szczytowego, który już nie jest otynkowany od wnętrza. Podczas prac musiano usunąć przylegającą do muru dawną konstrukcję dachu (il. 3). Przebudowa przebiegła w nieodległym od 1784 roku czasie, gdyż zastosowano podobną formę cegieł i zaprawy.

Z przebudową około 1784 roku należy wiązać także zamurowanie okna w ścianie północnej prezbiterium oraz przebudowę okna w ścianie południowej. Rezygnacja z okien w środkowych osiach korpusu mogła być też spowodowana pęknięciami murów. Z tego względu w kolejnym etapie, który trudno jednoznacznie umieścić chronologicznie, obmurowano dolną część szkarpy północno-zachodniej i wzmocniono pozostałe.

40 „Parafia Narodzenia NMP w Tulcach”, Dostęp 12 czerwca 2014.

41 Węzły ich narożników w miejscu styku z murami powinny zostać przebadane po zdjęciu tynków.

42 Z powodu usunięcia XVIII-wiecznej więźby wprowadzonej nad kościołem podczas rozbudowy oraz zastąpienia jej nową konstrukcją dachową wraz z masywnym stropem, a także nową wieżą, nie jest możliwe dokonanie pełnej analizy historii budowlanej obiektu. 
Zamurowanie okna w prezbiterium mogło też wynikać z dobudowy zakrystii. W tym celu wykuto wejście w ścianie północnej prezbiterium. $\mathrm{O}$ datowaniu świadczy zachowana stolarka drzwiowa i konstrukcja zawiasów hakowych. Podobne drzwi i ich zamocowanie prowadzą do kruchty bocznej. Prawdopodobnie postawiono ją razem z murami nowego korpusu lub w niewielkiej odległości czasowej. Mury tej dobudówki są cieńsze od zakrystii, co przemawia za tym, że powstała nieco później, ale w obrębie wspólnej fazy budowlanej.

Zakrystia musiała powstać na pewno przed połową XIX wieku (a być może jeszcze przed rozbudową), bo donosi o niej Józef Łukaszewicz w swoim opisie kościołów z 1858 roku. Przytacza między innymi zapis wizytacji z roku 1733 dotyczący płyty nagrobnej umieszczonej „na lewo od zakrystii”. Nie wiadomo jednak, czy odnosić to do stanu mu ówczesnego, czy do słów wizytatora ${ }^{43}$.

Obie części nawy przekryto drewnianym stropem, między częścią wschodnią a zachodnią wykonano arkadę. Możliwe, że w związku z tym zmieniono także konstrukcję więźby nad dawnym korpusem. Nowa, nieco niższa, spowodowała konieczność zamurowania dawnych otworów wentylacyjnych ${ }^{44}$.

\section{Faza IV \\ (nowożytna: XIX w. - 1945 r.)}

Kolejną, IV fazę budowlaną datowano hipotetycznie umieszczając w chronologicznych ramach obejmujących wiek XIX i pierwszą połowę XX. Podzielono ją na dwa etapy, z których pierwszy - do 1913 roku - jest najmniej udokumentowany.

Informacje o remoncie w roku 1837 oraz 1913 pojawiają się w literaturze, ale nieznany jest ich zakres ${ }^{45}$. Obie dobudówki - na co wskazuje, jak wspo-

43 Łukaszewicz, Krótki opis, 342. Kwestie te powinno rozwiązać pełne studium historyczne.

44 W ścianach od strony wschodniej wprowadzono też zapewne podczas budowy zamknięte łukiem odcinkowym wnęki szafowe. Węzły przewiązań ich narożników należałoby zbadać po zdjęciu tynków.

45 „Historia kościoła w Tulcach” na podstawie akt z Archiwum Archidiecezjalnego w Poznaniu i literatury, (maszynopis, Archiwum parafii w Tulcach), 7; Pamiątka z Tulec, 29-32. Sprawozdania konserwatorskie J. Kohtego z lat 1895-1917 nie donoszą o żadnych pracach. Zob. Julius Kohte, Bericht des Konservators der Denkmäler für die Provinz Posen über die Etatsjahre 1895/1896 und 1896/1897 (Posen: Arbeits- und Landarmenhause im Bojanowo, 1897); Julius Kohte, Bericht des Konservators der Denkmäler für die Provinz Posen über die Etatsjahre 1897/1898 und 1898/1899 (Posen: Arbeits- und Landarmenhause im Bojanowo, 1899); Julius Kohte, Bericht des Konservators der Denkmäler für die Provinz Posen über die Etatsjahre, 1899 bis 1902 (Posen: Arbeits- und Landarmenhause im Bojanowo, 1903); Julius Kohte, Bericht des Konservators der Denkmäler für die Provinz Posen über die Etatsjahre 1903 
mniano, stolarka drzwiowa w wejściach łączących je z kościołem - powstały raczej w fazie wcześniejszej (III). Podawane w literaturze datowanie na początek XX wieku może wiązać się z niezidentyfikowanymi bliżej pracami remontowymi, np. przebudową/wymianą konstrukcji dachu, ewentualną adaptacją dawnej kaplicy na kruchtę, powiększeniem okna w ścianie wschodniej zakrystii.

Prace zaliczone do drugiego etapu przyporządkowano okresowi 1914-1945. Miały one charakter tzw. gospodarczych remontów oraz drobnych napraw konserwatorskich ${ }^{46}$.

Faza V

(współczesna: po 1945 r.)

W ostatniej, V fazie budowlanej, trwającej do dziś od 1945 roku, wyróżniono trzy etapy. W trakcie dwóch pierwszych - w okresie od roku 1948 do końca lat pięćdziesiątych i następnym, od około roku 1966 do 1994 - nie wprowadzono istotnych przekształceń w strukturze świątyni (wymieniono m.in. okna i posadzkę) ${ }^{47}$. W trzecim etapie, w ostatnich dwóch dekadach lat, dokonano najpoważniejszych i jednocześnie najbardziej kontrowersyjnych z konser-

bis 1904 (Posen: Arbeits- und Landarmenhause im Bojanowo, 1905); Julius Kohte, Bericht über die Denkmalpflege in der Provinz Posen, 1 April 1905-31 März 1907 (Posen: Arbeits- und Landarmenhause im Bojanowo, 1907); Julius Kohte, Bericht über die Denkmalpflege in der Provinz Posen, 1 April 1907-31 März 1909 (Posen: Arbeits- und Landarmenhause im Bojanowo, 1909); Julius Kohte, Bericht des Konservators der Denkmäler für die Provinz Posen über die Etatsjahre 1 April 1909-31 März 1911 (Posen: Arbeits- und Landarmenhause im Bojanowo, 1911); Julius Kohte, Bericht des Konservators der Denkmäler für die Provinz Posen über die Etatsjahre 1 April 1911-31 März 1913 (Posen: Arbeits- und Landarmenhause im Bojanowo, 1913); Julius Kohte, Bericht des Konservators der Denkmäler für die Provinz Posen über die Etatsjahre 1 April 1913-31 März 1917 (Posen: Arbeits- und Landarmenhause im Bojanowo, 1918).

46 Udokumentowane zostały w postaci inskrypcji wykonanych w polach tynkowych umieszczonych na szczytach. Pozostałe informacje pochodzą z dokumentacji przechowywanych $w$ archiwum parafialnym w Tulcach oraz z literatury. Nie odnaleziono żadnych informacji $\mathrm{w}$ zachowanych sprawozdaniach konserwatorskich $\mathrm{z}$ okresu międzywojennego (tj. lat 1919-1939). Część odpisów sprawozdań pochodzących z różnych źródeł znajduje się w Archiwum Zakładu Konserwatorstwa UMK w Toruniu: „Poznański Okręg Konserwatorski, dr Nikodem Pajzderski - sprawozdania z działalności. Lata 1919-1931”. Materiały z Urzędu Wojewódzkiego Konserwatora Zabytków w Poznaniu, oprac. Jerzy Frycz, Mirosława Romaniszyn (teksty źródłowe, Toruń 1981, Archiwum Zakładu Konserwatorstwa UMK w Toruniu). Odpisy sprawozdań z pozostałych lat (z archiwum Akt Nowych w Warszawie) w zbiorach prywatnych dr K. Zimnej-Kaweckiej.

47 Informacje na podstawie dokumentów z archiwum parafii w Tulcach. Zob. „Parafia Narodzenia NMP w Tulcach". 
watorskiego punktu widzenia zmian. Mianowicie przeprowadzono rozbiórkę i „rekonstrukcję” wieży, odnowiono elewacje, usunięto osiemnastowieczną więźbę i stropy wprowadzając na ich miejsce stropy Kleina i nową konstrukcję dachową ${ }^{48}$.

\section{Wnioski}

Przeprowadzone badania architektoniczne kościoła w Tulcach skłaniają do kilku wniosków. Po pierwsze, w bardzo dużym stopniu zachowana jest struktura i forma pierwszego kościoła. Pozwala to dość dobrze zrekonstruować jego pierwotny wygląd, charakterystyczny dla około połowy XIII wieku gdzie nawa zakończona jest prezbiterium zamkniętym prosto. Niewyjaśniona pozostaje forma i funkcja części zachodniej o kubaturze najprawdopodobniej zbliżonej do prezbiterium. Nie wiadomo, czy znajdowała się w niej empora.

Po drugie, na ścianach i elewacjach zabytku przetrwało wiele bardzo istotnych z punktu widzenia historii technik budowlanych elementów, umożliwiających prześledzenie procesu średniowiecznej budowy - zwłaszcza ślady kolejnych etapów wznoszenia murów prezbiterium i nawy oraz oryginalne spoiny i zaprawy.

Jest to zatem zabytek o dużych walorach autentyczności, integralności i wartości historycznej ${ }^{49}$, cennych zwłaszcza dla poznania romańskiego wiejskiego budownictwa Wielkopolski, które nie doczekało się pełnej monografii opartej na wynikach współczesnych badań ${ }^{50}$. Wartość poznawczą świątyni zwiększają dobrze zachowane relikty, które mimo miejscowych przekształceń uwidoczniają pierwotny wygląd budowli oraz późnoromańską technikę budowlaną. Jej wyjątkowość podkreśla fakt, że wśród zachowanych obiektów z około połowy XIII wieku - w większości kamiennych - jest ona prawie kompletną trójczłonową ceglaną budowlą, której ściany artykułowane były zapewne trzema oknami.

Późniejsze przekształcenia romańskiej świątyni, kształtujące dzisiejszą jej formę, również zostały przyporządkowane chronologicznie. To rozpoznanie pozwala dostrzec te ich wartości, które powinny być uszanowane podczas

48 Informacje na podstawie dokumentów z archiwum parafii w Tulcach.

49 Janusz Krawczyk, „Dialog z tradycją w konserwatorstwie - koncepcja zabytkoznawczej analizy wartościującej”, Acta Universitatis Nicolai Copernici. Zabytkoznawstwo i Konserwatorstwo 44 (2013): 507-529.

50 Niejako wstępem do niej jest opublikowana dysertacja doktorska - zob. Różański, Jednoprzestrzenne. 
prac konserwatorskich. Brak takiej refleksji przyczynił się do zniszczenia cennej, osiemnastowiecznej więźby dachowej wraz ze stropem i konstrukcją wieży.

Dla dogłębnego poznania historii kościoła w Tulcach konieczne są jeszcze dodatkowe badania: pełne studium historyczne; punktowe odkrywki we wnętrzu (zwłaszcza przy styku korpusów w celu stwierdzenia, czy dobudowując korpus w XVIII wieku wykorzystano wcześniejsze mury) ${ }^{51}$; badania archeologiczne w obrębie styku murów obu części korpusów, które pozwoliłyby określić, jak wyglądała część zachodnia ${ }^{52}$; badania petrograficzne oraz stratygraficzne.

\section{Bibliografia}

Architektura romańska w Polsce. Bibliografia, oprac. Ewa Świechowska i Wojciech Mischke, wstęp Zygmunt Świechowski. Warszawa: Wydawnictwo DIG, 2001.

Architektura romańska w Polsce. Nowe odkrycia i interpretacje, red. Tomasz Janiak. Gniezno: Muzeum Początków Państwa Polskiego, 2009.

Architektura sakralna w początkach państwa polskiego (X-XIII w.), red. Tomasz Janiak

i Dariusz Stryniak. Gniezno: Muzeum Początków Państwa Polskiego, 2014.

Codex diplomaticus Majoris Polonia documenta, et jam typis descripta, et adhuc inedita complectens, annum 1400 attingentia, wyd. Ignacy Zakrzewski. T. 3, nr 1496. Poznań: Biblioteka Kórnicka 1879.

„Cudowny obraz Matki Boskiej w Tulcach”. Album Przewodnika Katolickiego 2 (1908). Filipowicz, Paweł, Leszek Kajzer, i Zbigniew Lechowicz. „Późnoromański, ceglany kościół w Strońsku nad Wartą w świetle najnowszych badań”. W Architektura romańska w Polsce. Nowe odkrycia i interpretacje, red. Tomasz Janiak, 467-487. Gniezno: Muzeum Początków Państwa Polskiego, 2009.

51 Do wyjaśnienia pozostaje m.in. sposób przewiązania murów dobudówek z korpusem (niewykluczone, że kruchtę boczną wykonano w tym samym czasie, co część zachodnią korpusu), określenie czasu powstania zakrystii. Kolejne odkrywki lica należy wykonać w miejscu wnęk: w ścianie wschodniej prezbiterium; północnej i południowej ścianie części zachodniej korpusu; w miejscu dawnego okna w ścianie zachodniej szczytu oraz na ścianach arkady między prezbiterium a nawą. Zbadanie tej arkady pozwoli określić, czy wprowadzona druga arkada - międzynawowa - powtarza jej formę, czy kształt obu tych elementów pochodzi z czasów rozbudowy z $1784 \mathrm{r}$.

52 Podobnie warto byłoby zbadać miejsce posadowienia zasypanej krypty w pobliżu zamurowanego portalu. Zlokalizowanie jej mogłoby pomóc nie tylko w ustaleniu pierwotnego układu, ale też w zrozumieniu przyczyn zniszczeń murów korpusu na osi środkowej. 
Filipowicz, Paweł, Leszek Kajzer, i Zbigniew Lechowicz. „Późnoromański kościół p.w. św. Urszuli i Jedenastu Tysięcy Dziewic w Strońsku nad Wartą. Interwencyjne badania architektoniczne w latach 2005-2006”. Ochrona Zabytków 4 (2006): 5-22.

„Historia kościoła w Tulcach” na podstawie akt z Archiwum Archidiecezjalnego w Poznaniu i literatury. Maszynopis, Archiwum parafii w Tulcach.

Jarzewicz, Jarosław. Kościoły romańskie w Polsce. Kraków: Wydawnictwo M, 2014.

Katalog zabytków sztuki w Polsce. T. 5 Województwo poznańskie, red. Teresa Ruszczyńska i Aniela Sławska. Z. 24 Powiat średzki, oprac. Teresa Ruszczyńska i Aniela Sławska. Warszawa: Instytut Sztuki PAN. Pracownia Inwentaryzacji Zabytków, 1964.

Kohte, Julius. Bericht des Konservators der Denkmäler für die Provinz Posen über die Etatsjahre 1895/1896 und 1896/1897. Posen: Arbeits- und Landarmenhause im Bojanowo, 1897.

Kohte, Julius. Bericht des Konservators der Denkmäler für die Provinz Posen über die Etatsjahre 1897/1898 und 1898/1899. Posen: Arbeits- und Landarmenhause im Bojanowo, 1899.

Kohte, Julius. Bericht des Konservators der Denkmäler für die Provinz Posen über die Etatsjahre, 1899 bis 1902. Posen: Arbeits- und Landarmenhause im Bojanowo, 1903.

Kohte, Julius. Bericht des Konservators der Denkmäler für die Provinz Posen über die Etatsjahre 1903 bis 1904. Posen: Arbeits- und Landarmenhause im Bojanowo, 1905.

Kohte, Julius. Bericht des Konservators der Denkmäler für die Provinz Posen über die Etatsjahre 1 April 1909-31 März 1911. Posen: Arbeits- und Landarmenhause im Bojanowo, 1911.

Kohte, Julius. Bericht des Konservators der Denkmäler für die Provinz Posen über die Etatsjahre 1 April 1911-31 März 1913. Posen: Arbeits- und Landarmenhause im Bojanowo, 1913.

Kohte, Julius. Bericht des Konservators der Denkmäler für die Provinz Posen über die Etatsjahre 1 April 1913-31 März 1917. Posen: Arbeits- und Landarmenhause im Bojanowo, 1918.

Kohte, Julius. Bericht über die Denkmalpflege in der Provinz Posen, 1 April 1905-31 März 1907. Posen: Arbeits- und Landarmenhause im Bojanowo, 1907.

Kohte, Julius. Bericht über die Denkmalpflege in der Provinz Posen, 1 April 1907-31 März 1909. Posen: Arbeits- und Landarmenhause im Bojanowo, 1909.

Kohte, Julius. Verzeichnis der Kunstdenkmäler der Provinz Posen. Bd. 3 Die Landkreise des Regierungsbezirks Posen, Lieferung 4. Berlin: Verlag von Julius Springer, 1896.

„Kościół p.w. Narodzenia NMP, Tulce”. „Karta Ewidencyjna Zabytków Architektury i Budownictwa”, oprac. M. Jarzewicz. Dokumentacja ewidencyjna, Tulce 1987, Archiwum Wojewódzkiego Urzędu Ochrony Zabytków w Poznaniu.

Kowalski, Jacek. „Großpolen“. W Mittelalterliche Architektur in Polen. Romanische und gotische Baukunst zwischen Oder und Weichsel. Bd. 1, Hg. Christofer Herrmann i Dethard von Winterfeld, 268-378. Petersberg: Michael Imhof Verlag, 2015.

Krassowski, Witold. Dzieje budownictwa i architektury na ziemiach Polski. T. 2. Warszawa: Arkady 1990. 
Krawczyk, Janusz. „Dialog z tradycją w konserwatorstwie - koncepcja zabytkoznawczej analizy wartościującej”. Acta Universitatis Nicolai Copernici. Zabytkoznawstwo i Konserwatorstwo 44 (2013): 507-529.

Łukaszewicz, Józef. Krótki opis historyczny kościołów parochialnych, kościółków, kaplic, klasztorów, szkółek parochialnych, szpitali i innych zakładów dobroczynnych w dawnej dyecezyi poznańskiej. T. 1. Poznań: Księgarnia Jana Konstantego Żupańskiego, 1858.

Pamiątka z Tulec, oprac. Mieczysław Noskowicz. Poznań: M. Noskowicz i Spł., 1917.

„Parafia Narodzenia NMP w Tulcach”. Dostęp 12 czerwca 2014. http://tulce.archpoznan. $\mathrm{pl} /$ historia.

„Poznański Okręg Konserwatorski, dr Nikodem Pajzderski - sprawozdania z działalności. Lata 1919-1931”. Materiały z Urzędu Wojewódzkiego Konserwatora Zabytków w Poznaniu, oprac. Jerzy Frycz, Mirosława Romaniszyn. Teksty źródłowe, Toruń 1981, Archiwum Zakładu Konserwatorstwa UMK w Toruniu.

Różański, Artur. „Czeskie i morawskie wzorce architektoniczne na terenie ziem polskich we wczesnym średniowieczu. Fakty i mity”. Archeologia Historica Polona 21 (2013): 31-47.

Różański, Artur. Jednoprzestrzenne kościoły romańskie z terenu Wielkopolski. Poznań: Wydawnictwo Poznańskie, 2010.

Średniowieczna architektura sakralna $w$ Polsce $w$ świetle najnowszych badań, red. Tomasz Janiak i Dariusz Stryniak. Gniezno: Muzeum Początków Państwa Polskiego, 2014.

Świechowski, Zygmunt. Architektura romańska w Polsce. Warszawa: Wydawnictwo DIG, 2000.

Świechowski, Zygmunt. Katalog architektury romańskiej w Polsce. Warszawa: Wydawnictwo DIG, 2009.

Tomala, Janusz. Architektura gotycka Wielkopolski. Kalisz: Edytor - Sławomir Woźniak, 2013.

Tomala, Janusz. Murowana architektura romańska i gotycka $w$ Wielkopolsce. T. 1 Architektura sakralna. Kalisz: Edytor - Sławomir Woźniak, 2007.

Tomaszewski, Andrzej. Romańskie kościoły z emporami zachodnimi na obszarze Polski, Czech i Węgier. Wrocław: Ossolineum, 1974.

Wnęk, Jacek. „Kult Matki Bożej Tuleckiej”. Praca magisterska, Wydział Teologiczny Katolickiego Uniwersytetu Lubelskiego, 1983.

Wołosz, Artur. „Romański kościół p.w. św. Małgorzaty w Rokiciu”. Notatki Płockie 34 (1989): 17-24.

Zachwatowicz, Jan. „Architektura”. W Sztuka polska przedromańska i romańska do schytku XIII wieku, red. Michał Walicki, seria: Dzieje sztuki polskiej, red. Michał Walicki et al., t. 1, 71-196. Warszawa: PWN, 1971.

Zimna-Kawecka, Karolina, i Maciej Prarat. „Projekt konserwatorski: Badania architektoniczne kościoła p.w. Narodzenia Najświętszej Marii Panny w Tulcach (pow. poznański)”. Dokumentacja konserwatorska, Tulce 2014, Archiwum parafii w Tulcach. 


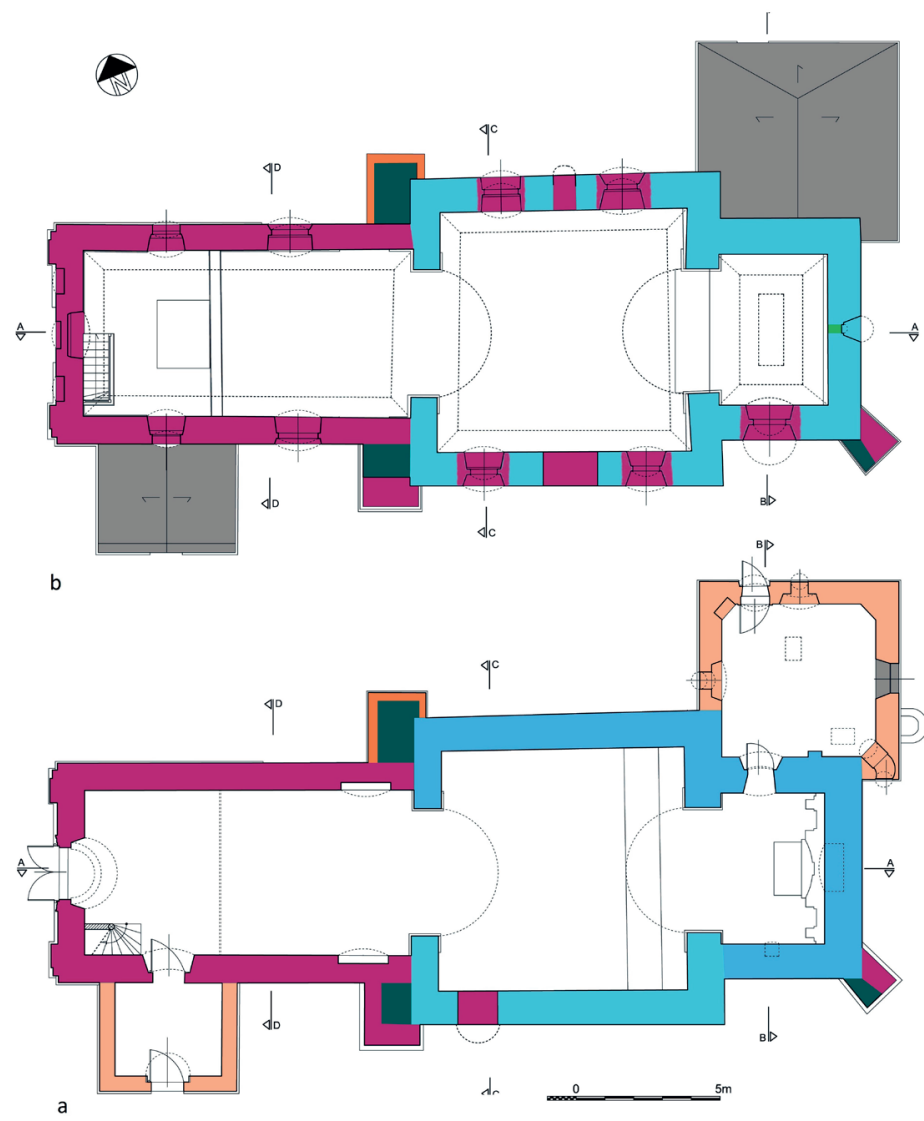

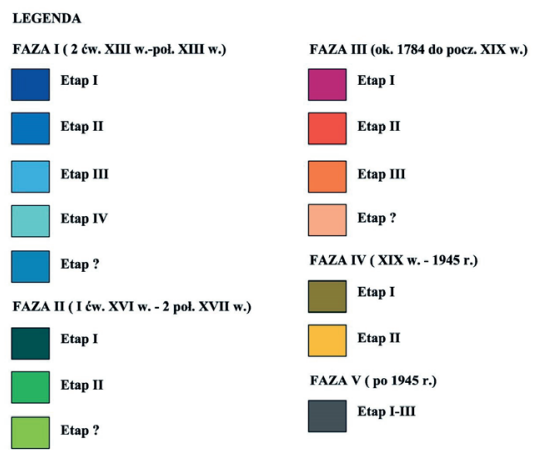

1. Późnoromański kościół w Tulcach. Rozwarstwienie chronologiczne. Oprac. Maciej Prarat, Karolina Zimna-Kawecka, 2014

a - rzut przyziemia, $b$ - rzut na poziomie empory 


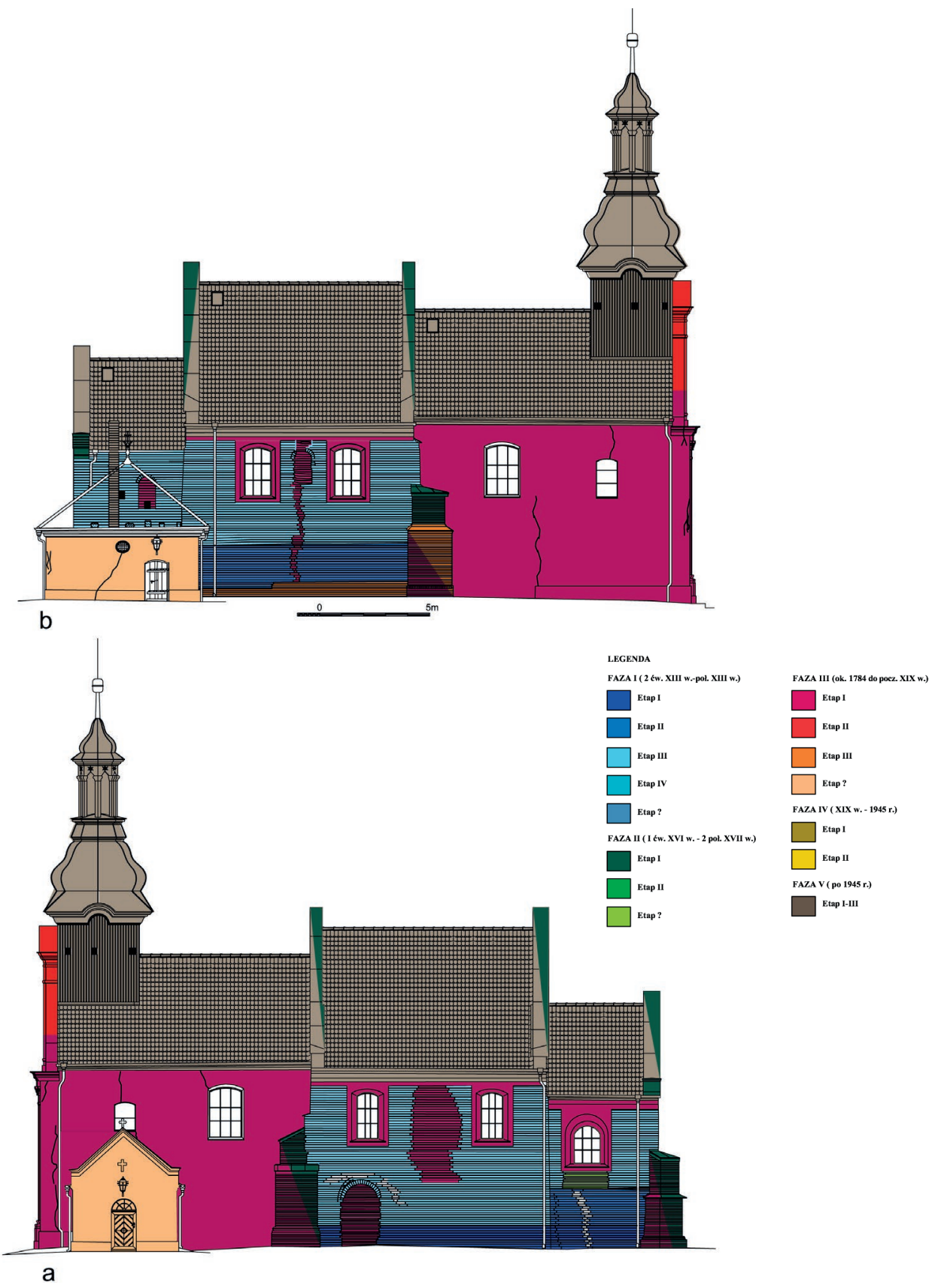

2. Późnoromański kościół w Tulcach. Rozwarstwienie chronologiczne. Oprac. Maciej Prarat, Karolina Zimna-Kawecka, 2014

a - elewacja południowa, b - elewacja północna 

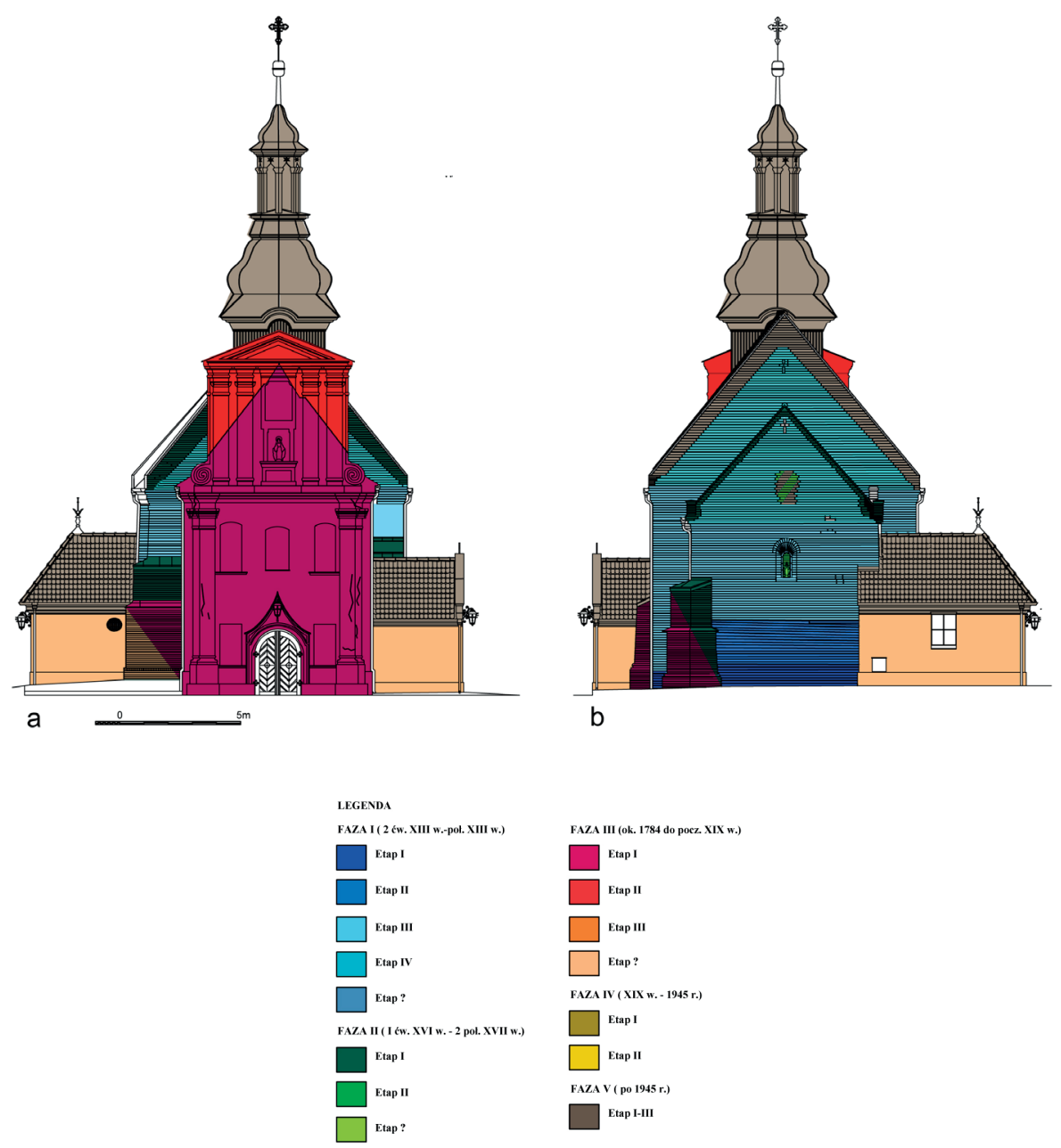

3. Późnoromański kościół w Tulcach. Rozwarstwienie chronologiczne. Oprac. Maciej Prarat, Karolina Zimna-Kawecka, 2014

a - elewacja zachodnia, $\mathrm{b}$ - elewacja wschodnia 


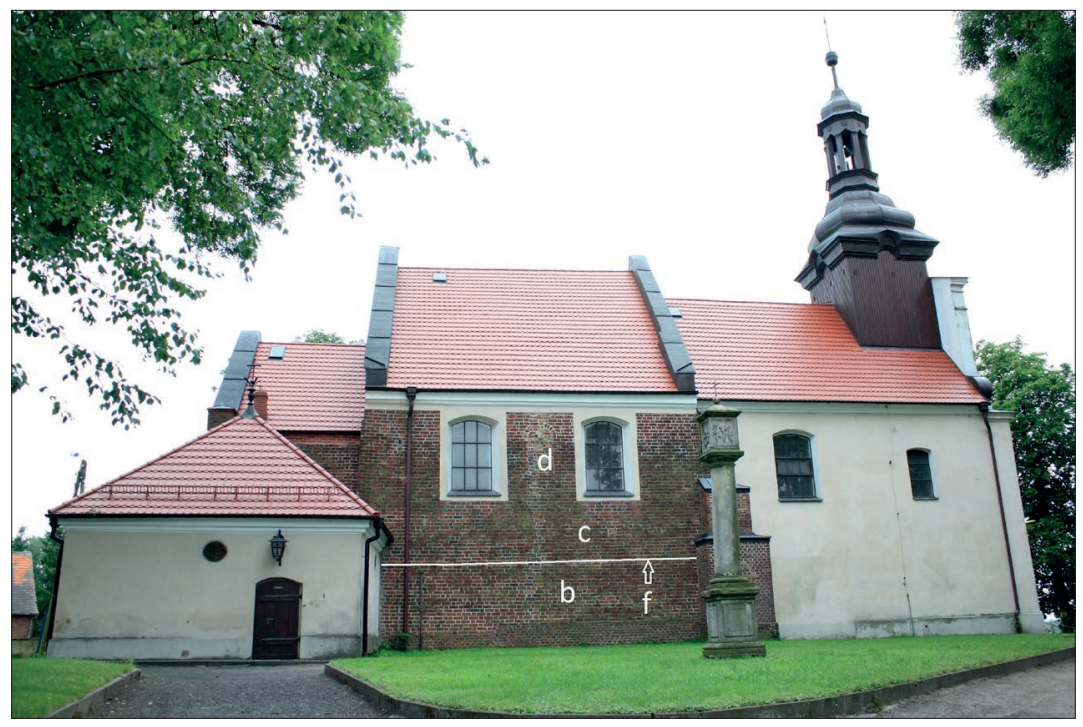

4. Późnoromański kościół w Tulcach. Elewacja północna. Oprac. Maciej Prarat, Karolina Zimna-Kawecka, 2014

f - linia warstwy wyrównującej, b - mur z I fazy 2. etapu, c - mur z I fazy 3. etapu, d - zamurowane okno romańskie

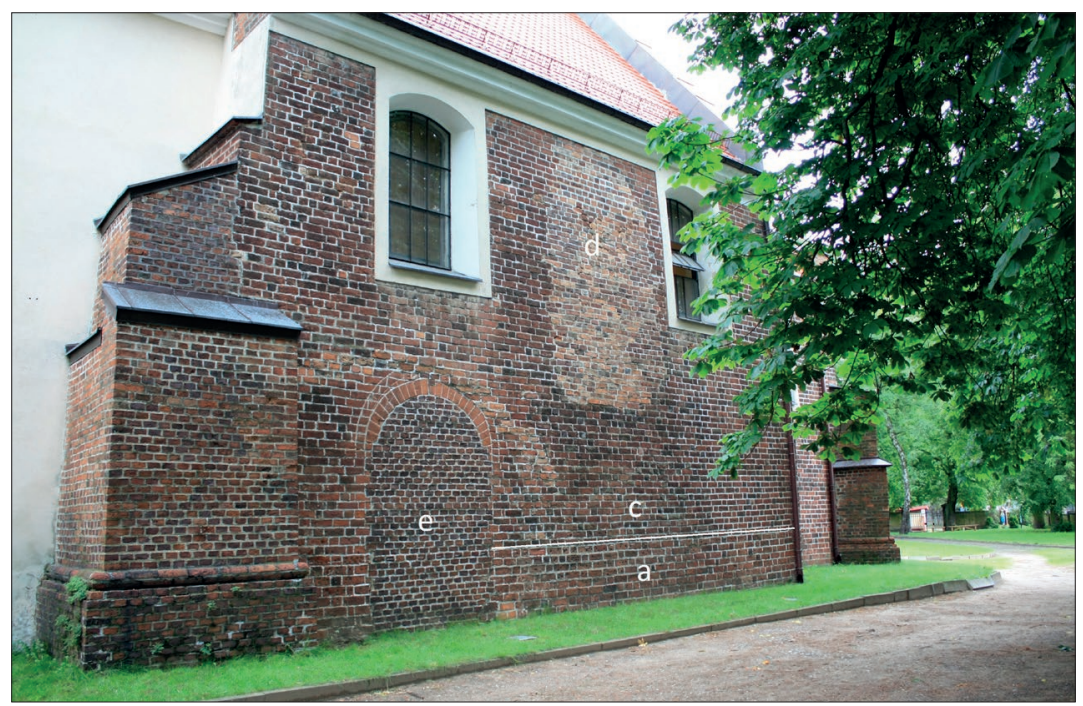

5. Późnoromański kościół w Tulcach. Elewacja południowa. Fot. Maciej Prarat, Karolina Zimna-Kawecka, 2014

a - mur z I fazy 1. etapu, c - mur z I fazy 3. etapu, d - zamurowanie (faza III, etap 1) w miejscu pierwotnego okna romańskiego, e - zamurowany (faza III, etap 1) pierwotny portal wejściowy 


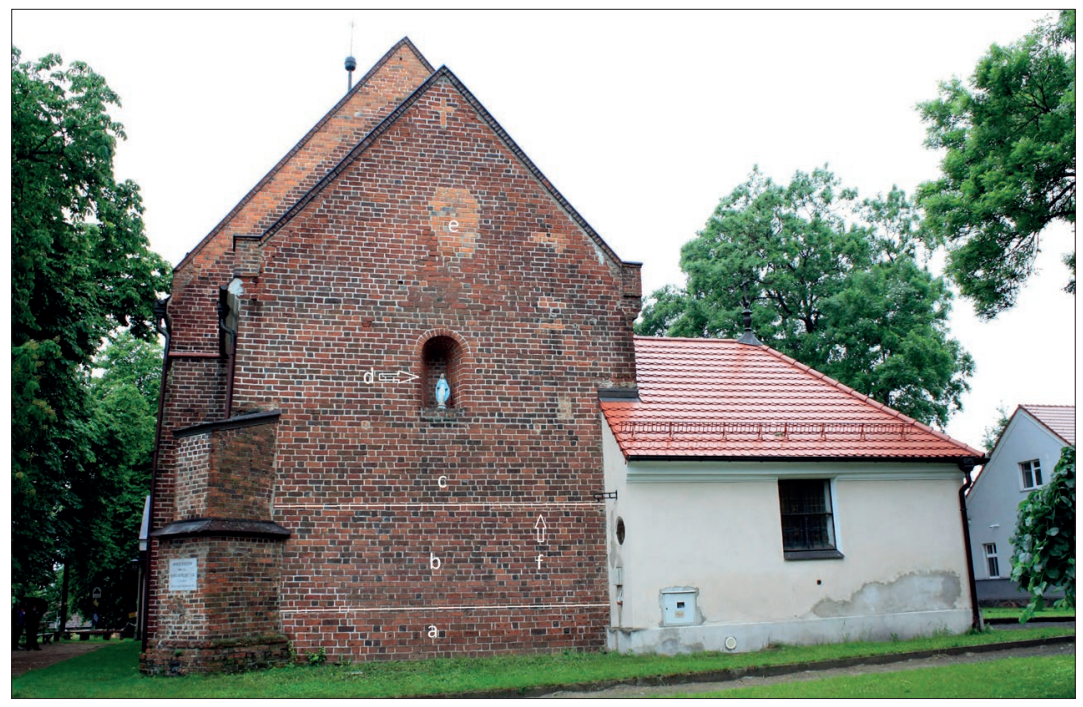

6. Późnoromański kościół w Tulcach. Elewacja wschodnia. Fot. Maciej Prarat, Karolina Zimna-Kawecka, 2014

a - mur z I fazy 1. etapu; b - mur z I fazy 2. etapu, c - mur z I fazy 3. etapu, d - pierwotne okno romańskie zamienione na blendę, e - zamurowanie (po okulusie?), $\mathrm{f}$ - warstwa wyrównująca

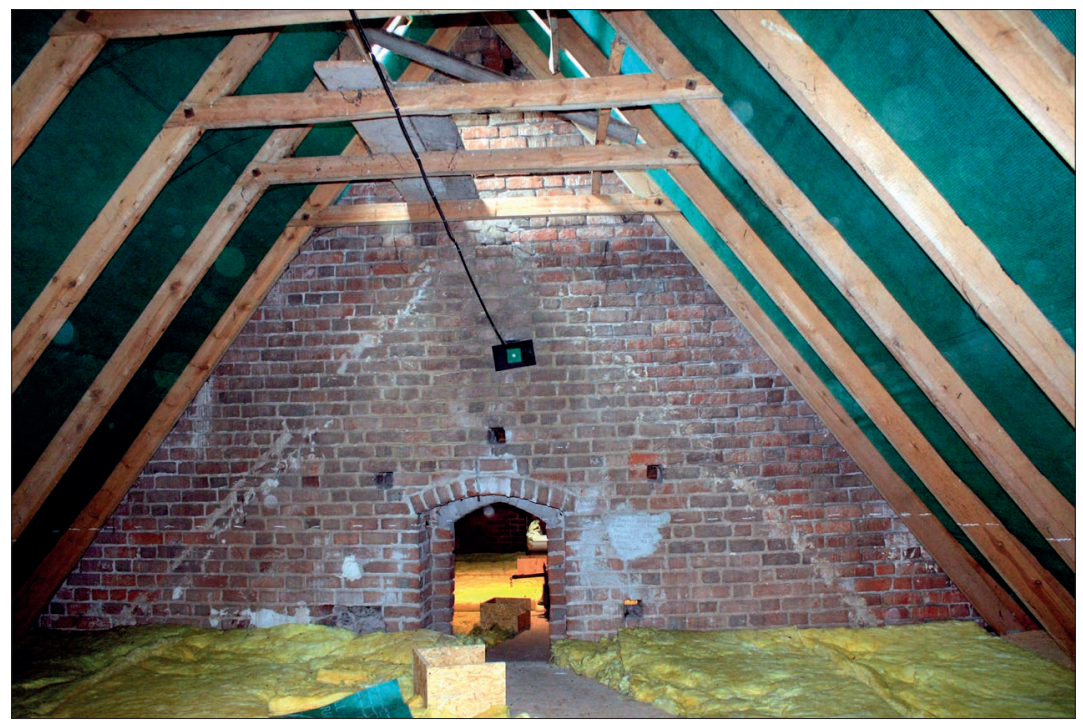

7. Późnoromański kościół w Tulcach. Szczyt zachodni (faza I, etap 4) części wschodniej nawy od strony zewnętrznej. Widoczne pierwotne przejście do trzeciego członu pierwotnej formy kościoła z zachowanym trójkątem połaci dachowych (wysokość odpowiadająca prezbiterium). Fot. Maciej Prarat, Karolina Zimna-Kawecka, 2014 


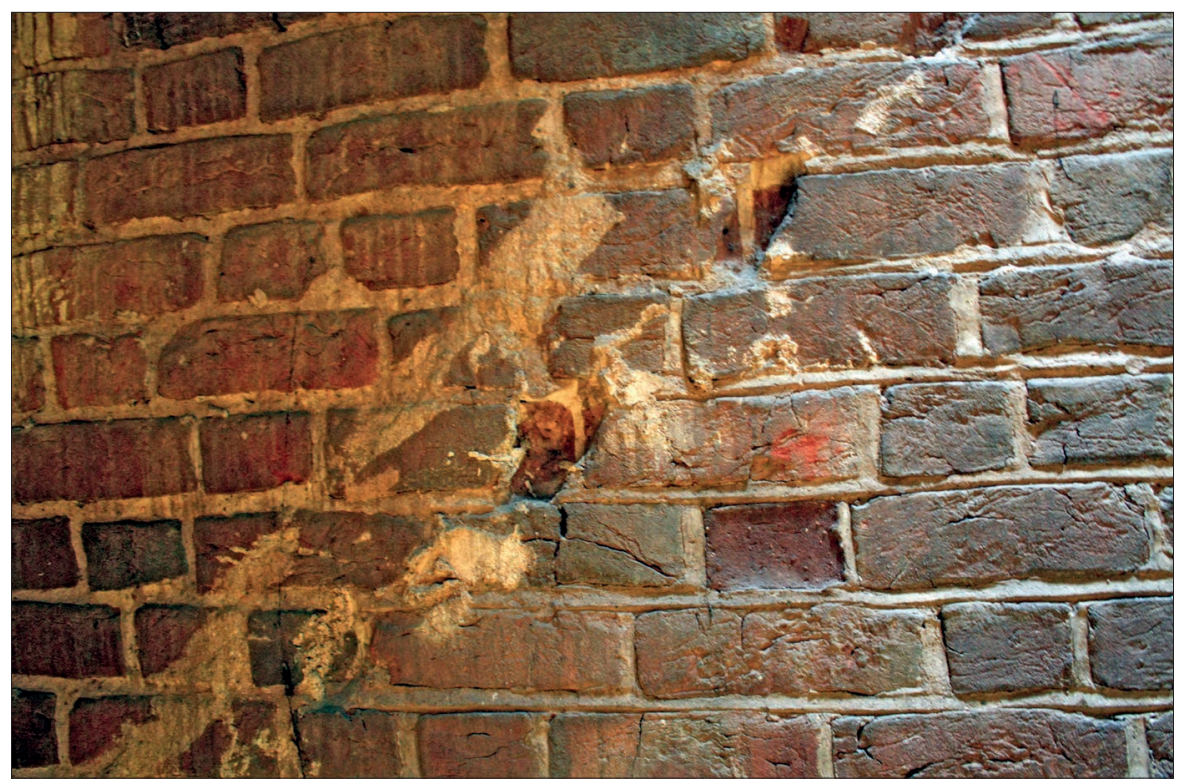

8. Późnoromański kościół w Tulcach. Szczyt zachodni (faza I, etap 4) części wschodniej nawy od strony zewnętrznej. Widoczne opracowanie spoiny jedynie pod krawędzią linii wcześniejszej połaci dachowej (świadczące o jej pierwotnym zarysie, zaplanowanym już podczas wznoszenia muru). Fot. Maciej Prarat, Karolina Zimna-Kawecka, 2014 

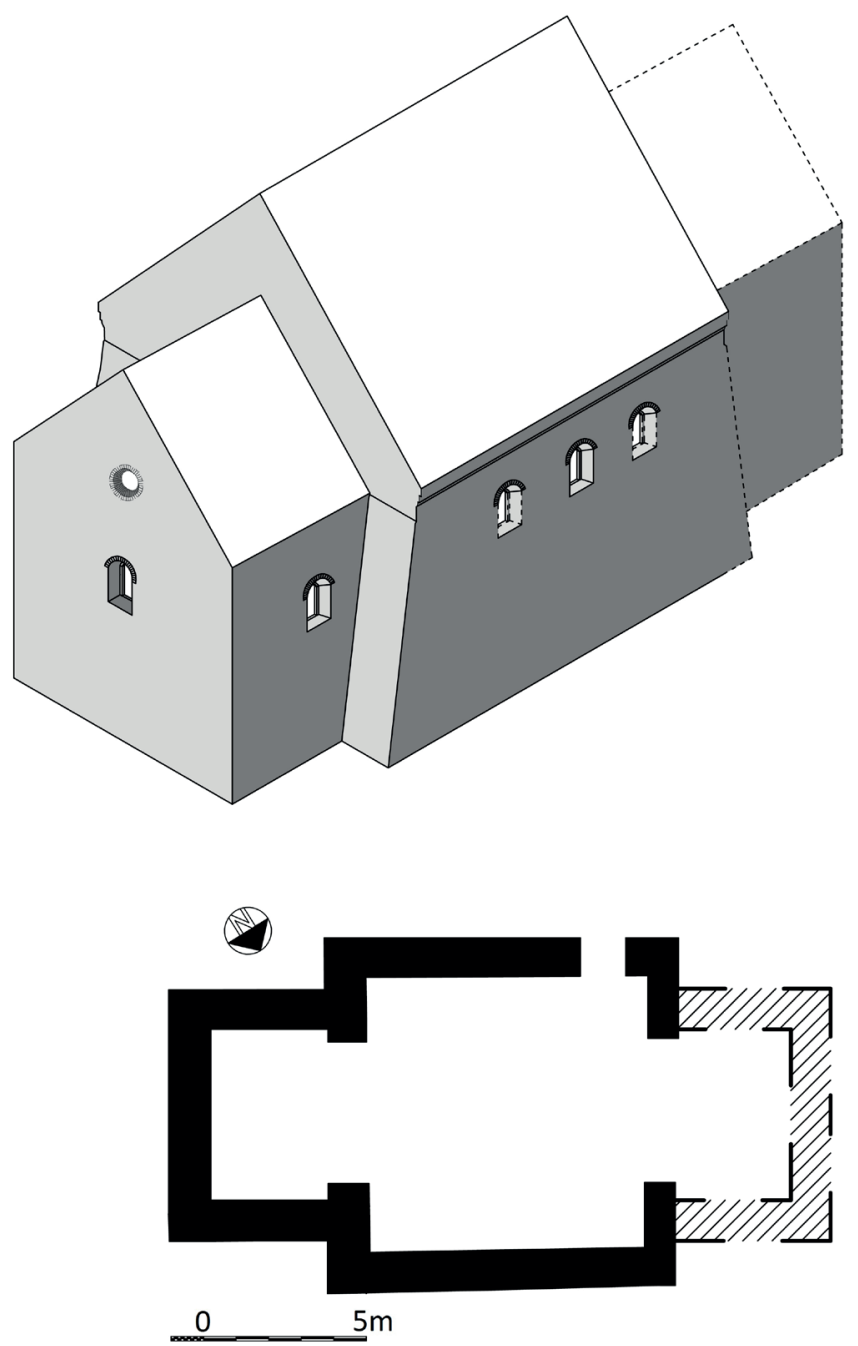

9. Późnoromański kościół w Tulcach. Hipotetyczna rekonstrukcja stanu pierwotnego (I faza). Oprac. Maciej Prarat, 2014

Linia przerywana - fragmenty rekonstruowane hipotetycznie: okulus w ścianie wschodniej prezbiterium, boczne okna nawy, szkarpa zachodnia, trzeci człon świątyni po stronie zachodniej 


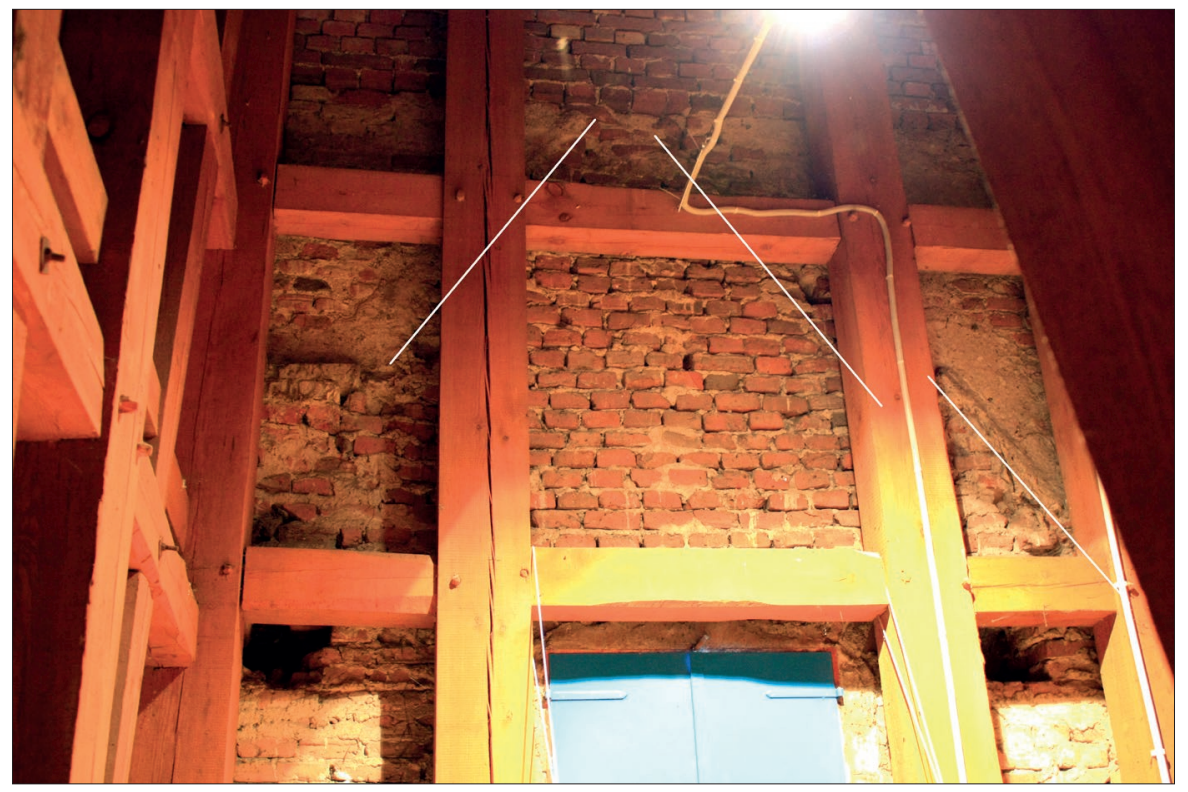

10. Późnoromański kościół w Tulcach. Szczyt zachodni na styku z wieżą. Fot. Maciej Prarat, Karolina Zimna-Kawecka, 2014

Linia - zarys wcześniejszego trójkątnego szczytu 